\title{
UMBATRA
}

Indonesian Journal of Anthropology

Volume 6 (2) Desember 2021 || eISSN 2528-1569

DOI : 10.24198/umbara.v6i2.33721

pISSN 2528-2115 || http://jurnal.unpad.ac.id/umbara

\section{Ketimpangan Gender di Layar Perak: Representasi Perempuan di Film Terlaris Indonesia}

\author{
Maghfira Fitra Yuliantini \\ Program Studi Antropologi, Fakultas Ilmu Sosial dan Ilmu Politik, Universitas Padjadjaran \\ maghfirafitray@gmail.com
}

\begin{abstract}
As part of popular culture, film is able to both reflect and shape the understanding and attitudes towards gender in a society. However, despite the increase of gender awareness in Indonesian society, there are still many filmmakers unfamiliar with gender issues. In fact, the unequal treatment and underrepresentation of female characters in film is a real issue within the Indonesian film industry. It is seen in the lack of films that positively representing women. Often, women are portrayed as being inferior to men. In addition, many films still sexually objectify women. This study attempts to analyze the depiction of women between highest-grossing films made by female directors and those directed by males. This paper aims to highlight how female participation within film production influences women's representation in popular films. The data is analysed using the Bechdel test - a tool to measure representation of women in fictional stories. Furthermore, this study examines female attitudes, characters, and their roles within the film, as well as the ways in which other roles respond to female roles. This study finds that women are represented in greater proportion and are portrayed more positively in films directed by women. In conclusion, gender portrayal within film is greatly influenced by the actors behind the scenes.
\end{abstract}

Keywords: gender, representation, Indonesian film, women

\begin{abstract}
Abstrak
Film sebagai budaya populer mampu mencerminkan sekaligus membentuk pemahaman dan sikap terhadap gender di dalam suatu masyarakat. Namun, meski kini kesadaran gender di masyarakat Indonesia telah meningkat, banyak sineas yang masih awam akan isu gender di film-film besutannya. Faktanya, ketimpangan perlakuan serta proporsi karakter perempuan dan laki-laki dalam film adalah masalah nyata di dalam industri film Indonesia. Hal tersebut terlihat dari minimnya film yang menampilkan representasi positif tentang perempuan, maupun film-film yang menggambarkan karakter perempuan sebaik laki-laki dalam media yang sama. Banyak peran perempuan yang tidak ditampilkan seimbang dengan lawan jenisnya, ditambah lagi, masih banyak film menjadikan perempuan obyek seksual. Penelitian ini membandingkan representasi perempuan di antara film terlaris Indonesia yang digarap oleh sutradara perempuan dan laki-laki. Penelitian ini bertujuan menyoroti pengaruh peran di balik layar terhadap representasi perempuan di da-
\end{abstract}


lam film populer. Data dianalisis menggunakan tes Bechdel (alat untuk mengukur representasi perempuan dalam cerita fiksi) serta dengan mengkaji sikap, karakter, dan peran perempuan di dalam film, juga cara peran lain menyikapi peran perempuan di sana. Penelitian ini menemukan bahwa perempuan mendapatkan proporsi yang lebih besar dan ditampilkan secara lebih positif dalam film-film yang disutradarai oleh perempuan. Maka dapat disimpulkan bahwa penggambaran representasi gender amatlah dipengaruhi oleh pelaku di balik layar film tersebut.

Kata kunci: gender, representasi, film Indonesia, perempuan

\section{Pendahuluan}

Budaya populer telah menjadi sajian utama yang dikonsumsi dalam kehidupan sehari-hari. Budaya populer terus diproduksi dan direproduksi dengan dinamis mengikuti peradaban zaman sehingga cenderung dianggap sebagai suatu hal yang biasa. Budaya populer adalah budaya yang lahir karena media; dan jika media mampu memproduksi sebuah bentuk budaya, maka publik akan menyerapnya dan menjadikannya sebagai sebuah bentuk kebudayaan (Umarella, 2012). Media berperan sebagai wadah untuk menyebarkan dan mempopulerkan suatu produk budaya, sehingga apapun yang diproduksi oleh media akan diterima oleh publik sebagai suatu nilai (budaya) bahkan menjadi kiblat panutan masyarakat (Umarella, 2012). Di sisi lain, media juga dapat merefleksikan kebudayaan dari suatu masyarakat, sehingga ia menjadi sesuatu yang bersifat dua arah; media memengaruhi masyarakat, dan sebaliknya, masyarakat juga memengaruhi media.

Film sebagai salah satu bentuk media massal dan artefak budaya populer yang tidak dapat dipisahkan dari masyarakat kini telah berkembang begitu pesat. Hiburan dalam wujud seni pertunjukan ini telah menjadi industri yang amat menjanjikan di Indonesia. Setiap tahun, puluhan juta penonton berbondong-bondong membeli tiket untuk menonton film. Data Suara Pembaruan (2020) menunjukkan bahwa penonton film nasional pada 2018 dan 2019 berjumlah 51 juta lebih penonton per tahun, dengan raupan keuntungan mencapai puluhan hingga ratusan miliar per filmnya.

Media memainkan peran yang besar dalam memengaruhi kehidupan sehari-hari masyarakat karena media berpengaruh pada bagaimana masyarakat memandang dunia secara umum (Alzahrani, 2016). Begitu pula film yang mampu memberikan pengaruh kepada cara pandang masyarakat; sekaligus mencerminkan pemahaman dan sikap dari suatu masyarakat terhadap isu tertentu, salah satunya adalah isu gender. Di dalam setiap film, ada citra yang ditampakkan akan lelaki dan perempuan. Citra-citra ini digambarkan dalam cara yang berbeda dengan karakteristik yang berbeda dan memiliki makna yang berbeda pula (Alzahrani, 2016).

Gender sendiri telah menjadi isu yang cukup hangat di industri perfilman Hollywood (Kunsey, 2019), tetapi amat disayangkan intensitasnya di Indonesia tidak sama besarnya. Hal ini lalu bekerja seperti gerbang tanpa penjaga yang semestinya memeriksa tiap tiket pengunjung; mereka dapat terus lolos tanpa ada pemindaian. Film-film Indonesia terus diproduksi tanpa ada dorongan massal untuk menjadikan para sineas dan karya-karyanya kelak menjadi lebih melek gender.

Ketimpangan perlakuan dan proporsi yang tidak seimbang pada karakter perempuan dan lelaki di dalam film adalah hal pertama yang dapat kita perhatikan. Masyarakat Indonesia kini memang telah lebih peka terhadap isu gender, tetapi masih banyak sineas yang awam terhadap isu ini. Di Indonesia, secara khusus belum banyak peran perempuan yang digambarkan dengan karakter yang kuat dan berdaya seperti karakter laki-laki. Di sisi lain, justru banyak film yang masih mengob- 
jektifikasi perempuan secara seksual seperti yang sering dijumpai dalam film horor (Ayun, 2015).

Film umumnya mencerminkan sikap budaya yang berlaku terhadap peran, norma, sikap, dan harapan akan gender (Kunsey, 2019). Penggambaran relasi gender yang negatif dalam film berpengaruh pada penyebaran stereotip gender. Sebab-akibat ini seringkali menghasilkan lingkaran setan karena stereotip sosial memengaruhi para sutradara laki-laki, yang kemudian mereproduksi stereotip gender yang terlebih dahulu ada (Kunsey, 2019).

Selain di depan layar, perempuan juga tidak mendapatkan kesempatan yang sebanding dengan laki-laki di balik layar. Di antara 80 film terlaris Indonesia yang dicatat filmindonesia.or.id (2021), hanya ada dua film saja yang disutradarai oleh perempuan yakni " $M y$ Stupid Boss" oleh Upi Avianto di posisi ke12, dan "Dua Garis Biru” oleh Ginatri S. Noer di posisi ke-22. Hal ini berarti bahwa perempuan hanya menempati $2,5 \%$ posisi di daftar film terlaris Indonesia.

Indikator kehadiran aktif perempuan di bidang film dan karya fiksi, serta ketidaksetaraan gender dalam fiksi dapat diukur melalui tes Bechdel (Garcia, Weber, dan Garimella, 2013). Tes ini bermula dari lelucon di dalam komik Dykes to Watch Out For oleh Alison Bechdel pada 1985 mengenai gender role dalam film komersial. Namun, seiring waktu dan tahun, tes ini menjadi semakin populer sebagai ukuran representasi perempuan di dalam film, atau karya fiksi pada umumnya. Cara pengukuran tes ini yaitu dengan melihat apakah ada dua perempuan atau lebih yang saling berbicara dan membicarakan hal-hal selain laki-laki. Selain itu, ada pula indikator opsional yaitu bahwa kedua perempuan itu mesti memiliki nama. Tes Bechdel diterapkan sebab ia mampu mengidentifikasi bahwa peran laki-laki di media seringkali membicarakan topik-topik dalam ranah yang lebih luas ketimbang perempuan; sedangkan perempuan cenderung didapati hanya berbincang mengenai lelaki (Bouchat, 2019).
Bouchat (2019) menyatakan bahwa film yang tidak lulus tes Bechdel dapat memberikan gambaran yang keliru tentang interaksi antar perempuan dalam kehidupan nyata. Adegan dua wanita yang saling berinteraksi dan hanya membicarakan hal-hal mengenai laki-laki dapat menumbuhkan dan melanggengkan gagasan pada penonton bahwa jenis percakapan ini normal di antara perempuan. Representasi semacam ini kemudian dapat menumbuhkan sikap negatif terhadap perempuan. Laki-laki yang mendominasi baik melalui peran-peran di layar perak atau pelaku di balik layar menunjukkan kesenjangan kesempatan bagi sineas perempuan untuk ikut andil di dalam industri film.

Representasi perempuan di dalam film Indonesia perlu dikaji dalam konteks antropologi gender. Film sebagai budaya populer berperan sebagai cerminan dari tatanan sosial-budaya suatu masyarakat. Hal-hal yang ditampilkan di dalam film, kurang-lebih melukiskan nilai dan norma di dalam satu kebudayaan, dan sebaliknya, apa yang ditampakkan di dalam film mampu memengaruhi audiens dalam penetapan nilai dan normanya. Masyarakat akan cenderung, secara sadar maupun tidak, menerapkan apa yang mereka konsumsi melalui film-film tersebut. Oleh karena itu, penting untuk mengkaji topik ini melalui antropologi gender, sebab ia memungkinkan penggalian yang lebih dalam tentang bagaimana sebenarnya representasi perempuan di dalam media film, dan bagaimana pelaku di balik layar menentukan penggambaran gender padanya.

Mayoritas artikel yang membahas penggambaran gender dalam film bersumber dari luar negeri, salah satunya adalah penelitian Montasseri, Khaghaninejad, dan Moloodi (2020) yang membahas representasi gender dalam film-film Amerika. Hasil penelitian tersebut menemukan bahwa laki-laki dan perempuan direpresentasikan dalam film secara berbeda berdasarkan stereotipe gender. Laki-laki diasosiasikan dengan jabatan yang tinggi dan pekerjaan dan aktivitas "kelas atas". Di sisi lain, perempuan digambarkan sebagai sosok 
yang inferior, lebih banyak berperan dalam pengasuhan anak, memiliki pendapatan yang rendah, dan dihubungkan dengan aspek seksual (Montasseri et al., 2020).

Kurangnya artikel mengenai penggambaran gender di film-film Indonesia membuat penulis melakukan penelitian yang serupa seperti yang dilakukan pada industri film di Hollywood, tetapi dengan menggunakan film Indonesia sebagai objek penelitian. Penelitian ini akan melihat bagaimana perbandingan representasi perempuan dalam film yang disutradarai oleh laki-laki dan perempuan.

\section{Kajian Pustaka}

\section{Peran Gender}

Selama ini istilah jenis seks dan gender dikenal untuk merujuk pada perbedaan jenis kelamin. Namun, sebenarnya keduanya adalah hal yang berbeda. Pengertian seks atau jenis kelamin merupakan pembagian dua jenis kelamin manusia yang ditentukan secara biologis, dan bersifat permanen (tidak dapat dipertukarkan antara laki-laki dan perempuan) (Astuti, 2016). Ciri-ciri biologis kedua jenis kelamin sama di semua tempat, di semua budaya dari waktu ke waktu, dan tidak dapat dipertukarkan satu sama lain.

Berbeda dengan seks, Astuti (2016) melanjutkan bahwa perwujudan konsep gender adalah sifat-sifat yang melekat pada lelaki maupun perempuan yang dikonstruksi secara sosial dan budaya. Misal, laki-laki digambarkan dengan karakter dan sifat yang kuat, gagah, keras, disiplin, pintar, dan lebih cocok untuk bekerja di luar rumah; sedangkan perempuan digambarkan memiliki karakter lemah lembut, keibuan, halus, cantik, dan lebih cocok untuk bekerja di dalam rumah (megurus anak, memasak, dan membersihkan rumah) (Astuti, 2016).

Sosialisasi gender pada umumnya memiliki tendensi bahwa laki-laki dan perempuan memiliki peran yang berbeda satu sama lain. Laki-laki umumnya dibesarkan untuk menyesuaikan diri dengan peran gender maskulin dan perempuan dibesarkan untuk menyesuaikan diri dengan peran gender feminin (Crespi, 2003 dikutip Nurwahyuni, 2015).

Layaknya drama yang tengah diperankan oleh seseorang, peran gender seperti sebuah naskah yang harus diikuti oleh laki-laki dan perempuan dalam bertindak maskulin atau feminin (Brannon, 1996, dikutip Amelia, 2013). Peran gender menentukan nilai-nilai, atau bagaimana perempuan dan laki-laki dinilai secara berbeda.

Peran gender menciptakan stereotip di dalam masyarakat, yaitu pelabelan yang diawali dengan proses persepsi tentang berbagai macam ciri dan sifat-sifat personal yang melekat (seakan permanen) pada sekelompok orang (Popenoe, 1983, dikutip Nurwahyuni, 2015). Maka dari itu, stereotip gender beranggapan bahwa laki-laki harus mempunyai sifat-sifat tertentu dan melakukan hal-hal tertentu, dan perempuan memiliki sifat-sifat yang lain dan harus melakukan hal-hal lain (Richmond-Abott, 1992, dikutip Perdana, 2014). Stereotip ini juga memiliki arti bahwa laki-laki dan perempuan harus mengikuti peran gender yang telah dikonstruksi untuk dapat diterima secara sosial. Laki-laki dan perempuan belajar tentang karakter yang dianggap sesuai dan pantas bagi kedua gender tersebut melalui sosialisasi (Nurwahyuni, 2015).

Contoh dari stereotip gender tipikal adalah, femininitas meliputi ekspektasi untuk menjadi domestik, hangat, cantik, emosional, dependen, lemah secara fisik, dan pasif (Moore, dikutip Fatimah, Sili, dan Asanti, 2019). Selain itu, perempuan dilihat memiliki sifat-sifat yang merawat, sensitif, dan patuh. (Cranny-Francis et al., 2003, dikutip Fatimah et al., 2019). Berkebalikan dari itu, laki-laki dipandang sebagai seseorang yang lebih kompetitif dan tidak seemosional perempuan. Stereotip maskulin digambarkan sebagai hal-hal yang tidak emosional, kuat secara fisik, independen, aktif, dan agresif (Moore, dikutip Fatimah et al., 2019).

Perbedaan gender sesungguhnya tidak men- 
jadi masalah sepanjang tidak melahirkan ketimpangan gender (gender inequality) (Astuti, 2016). Namun, timbul persoalan ketika perbedaan gender telah melahirkan berbagai ketimpangan. Perempuan masih tetap menduduki posisi tertinggi sebagai korban ketimpangan gender, walaupun tidak menutup kemungkinan bahwa laki-laki juga menjadi korban ketimpangan gender (Astuti, 2016). Di dalam hal ini, selain sebagai suatu elemen konstitutif dari hubungan sosial berdasarkan perbedaan jenis kelamin, gender juga merupakan cara utama untuk menandakan hubungan kekuasaan (Khaliq, 2005 dikutip Astuti, 2016).

Isu gender menjadi semakin kompleks ketika stereotip peran gender diberlakukan pada karakter-karakter di film. Hal yang ditampilkan di dalam media tentang gambaran perempuan akan memengaruhi bagaimana perempuan menilai dirinya (Perdana, 2014). Konten yang ditampilkan media membuat audiensnya percaya bahwa streotip-stereotip gender adalah hal yang normal.

\section{Media Massa dan Representasi Gender}

Film dan media elektronik adalah bagian yang tak terpisahkan dari keseharian sebagian besar masyarakat. Penggambaran gender juga kemudian menjadi peristiwa biasa di keseharian. Masyarakat dari berbagai kalangan usia mempelajari gender dari hiburan, iklan, internet, dan pemberitaan. Media-media ini lalu mulai memengaruhi orang tentang nilai-nilai kebudayaan.

Film merupakan bentuk media yang dapat memengaruhi stereotip dalam masyarakat (Perdana, 2014). Film mengkonstruksi stereotip secara kuat melalui latar, pemilihan gambar, percakapan, dan lakon. Media massa yang selanjutnya berperan dalam mentransformasikan simbol-simbol, akan membawa ideologi tertentu yang ditujukan kepada masyarakat (Perdana, 2014). Setiap simbol membawa banyak makna, namun akan selalu ada makna dominan yang diharapkan dapat ditangkap oleh audiens (Perdana, 2014).

Penggambaran media bisa jadi sangat kuat dan persuasif sehingga penggambarannya bertransformasi menjadi standar penilaian orang lain tentang hal yang normal dan mereka inginkan untuk hidup mereka (Brannon, 2017). Morgan dan Shanahan (2010) menyatakan bahwa orangorang yang menghabiskan waktu menonton televisi lebih banyak, cenderung menerima dunia nyata dengan cara-cara yang umum dijumpai di dunia fiksi televisi. Maka dari itu, media bisa menjadi lebih penting dari pengalaman personal dalam membentuk sikap dan perilaku.

Penggambaran di dalam media menanamkan gagasan, sikap, dan imajinasi kepada orangorang bahwa hidupnya harus sesuai dengan penggambaran media (Brannon, 2017). Perusahaan menciptakan makna gender yang dikomunikasikan melalui struktur dan praktik budaya (Onea, 2015). Keputusan sosial yang melekat pada identitas pribadi, mengarahkan individu menjadi suatu tipe tertentu. Hal ini menjadi dasar desainer dalam menangkap fenomena atau kode-kode sosial untuk ditransformasikan ke dalam proses berpikir kreatif yang digunakan sebagai mainstream, ketika mereka mulai memposisikan gagasan tentang femininitas dan maskulinitas (Astuti, 2016). Media terus melanggengkan peran-peran restriktif bagi laki-laki dan perempuan dengan membedakan perempuan dan laki-laki dan membaginya ke dalam kategori-kategori stereotipikal, dan kemudian menyajikannya dengan cara yang menarik (Brannon, 2017).

Masalah-masalah yang harus diperhatikan dalam representasi gender pada media tidak berhenti di sana. Berdasarkan penelitian Bouchat (2019) terhadap 200 film, The Geena Davis Inclusion Quotient menemukan bahwa hanya $17 \%$ dari film-film penjualan terbaik yang memiliki peran utama perempuan, yang kemudian kebanyakan adalah karakter komedik. Karakter laki-laki sendiri menduduki waktu layar dua kali lipat dibandingkan perempuan dan bicara lebih banyak dibandingkan karakter perempuan. Para perempuan dalam cerita fiksi pun dinilai terlalu sederhana dan selalu ditunjukkan dalam hubungannya dengan laki-laki. Di dalam film dengan perempuan sebagai peran utama, karakter laki-laki 
berbicara dalam jumlah waktu yang hampir sama banyaknya seperti peran utama perempuan. Namun, ketika peran utamanya adalah laki-laki, karakter perempuan berbicara lebih sedikit dibandingkan peran utama laki-laki (Bouchat, 2019).

Selain itu, peran-peran perempuan sering ditampakkan inferior dan berada di bawah kekuasaan laki-laki. Adegan perempuan yang menerima kekerasan (entah verbal, fisik, atau seksual) dari laki-laki tidak jarang ditampilkan. Representasi kekerasan kepada perempuan membuat mereka takut terhadap tindakan kekerasan dari laki-laki, dan menguatkan keinginan laki-laki untuk melakukan kekerasan kepada perempuan (Custers dan Bulck, 2012).

Kekerasan dalam bentuk seksisme juga ditampilkan melalui dua cara yang bertolak belakang, yakni dengan sikap benevolent (baik hati) dan hostile (bermusuhan) (Piano et al., 2014). Contoh, peran laki-laki mungkin memiliki sikap tidak bersahabat terhadap seorang perempuan, sedangkan laki-laki lain melindungi perempuan tersebut. Ideologi seksis ini berfungsi untuk melegitimasi superioritas laki-laki dengan sistem kepercayaan yang kuat, yang terdiri dari dua cara yang berbeda dan saling melengkapi, yakni benevolent sexism dan hostile sexism (Piano et al., 2014). Hostile sexism didasarkan pada penegasan inferioritas 'alami' perempuan, yang membenarkan permusuhan secara terang-terangan terhadap mereka; perempuan dianggap sebagai lawan; sedangkan benevolent sexism malah menyematkan sejumlah kualitas positif pada perempuan, mendefinisikan mereka sebagai makhluk yang berharga, untuk dilindungi, dipuja, dan disanjung (Piano et al., 2014). Seksisme yang benevolent pun seringkali diekspresikan dengan cara yang halus, sehingga sulit untuk dikenali. Seksime tipe ini kemudian dapat lebih mudah diterima secara sosial, melegitimasi ketidaksetaraan sosial (Piano et al., 2014). Kedua tipe seksisme ini tentu tidak asing bagi penonton di cerita-cerita film, sebab peran lelaki acapkali digambarkan melakukan kekerasan secara terang-terangan kepada wanita, dan/atau peran lelaki (lain) ditampakkan menjadi pelindung yang memuja dan menggambarkannya sebagai makhluk berharga yang perlu dijaga dari marabahaya, yakni seksisme hostile.

Memandang film dengan perspektif gender memungkinkan adanya penemuan persoalan-persoalan yang menarik untuk dibahas, yakni stereotip gender yang ditanamkan melalui peran, karakter, juga posisi mereka di dalam cerita. Selain itu, kekuatan pelaku di balik layar dalam menampakkan gambaran-gambaran tersebut dalam karyanya juga perlu diperhitungkan. Sebab, seiring waktu pandangan penonton sinema memiliki kemungkinan untuk mulai menyerupai gambaran dunia di layar, dan bukan tidak mungkin representasi dunia di media kemudian dapat berangsur menjadi kejadian di realita (Custers dan Bulck, 2012). Oleh karena itu, penting untuk mengukur interaksi antar perempuan untuk melihat bagaimana dan seberapa sering hubungan perempuan digambarkan dalam film.

\section{Metode}

Metode yang digunakan dalam penelitian ini adalah metode deskriptif. Data primer dalam penelitian ini berupa enam film, dan data sekunder diperoleh melalui studi pustaka terhadap beberapa artikel terdahulu yang membahas tentang isu gender pada film dan antropologi gender. Enam film yang dianalisis dalam film ini dikategorikan menjadi tiga sesuai genre yaitu: genre komedi: "Warkop DKI Reborn: Jangkrik Boss! Part 1" (2016) dan "My Stupid Boss" (2016); genre drama remaja: "Dilan 1990" (2018) dan "Dua Garis Biru" (2019); genre horor: "Pengabdi Setan" (2017) dan "Aku Tahu Kapan Kamu Mati” (2020). Keenam film ini dipilih sebagai perbandingan film Indonesia dengan penjualan terbaik dari sutradara perempuan dan sutradara laki-laki. Film-film ini dipilih dengan penilaian persamaan jenis cerita (fiksi), genre, dan jumlah penonton yang tinggi serta cakupan audiensnya yang luas.

Analisis data dalam penelitian ini terdiri dari beberapa langkah. Langkah pertama yakni mengukur film menggunakan tes Bechdel. Tes 
ini memiliki tiga tahap yakni, 1) melihat apakah ada dua perempuan atau lebih; 2) melihat apakah mereka berbicara satu sama lain; dan, 3) melihat apakah mereka membicarakan hal selain laki-laki. Analisis dilanjutkan dengan melihat dan menelaah sikap dan karakter perempuan yang ditampilkan, dan bagaimana peran-peran lain (terkhususnya lelaki) menyikapinya, serta bagaimana posisi peran-peran perempuan dan laki-laki serta kontribusinya pada jalan cerita. Selanjutnya dilakukan penafsiran dari penggambaran tersebut untuk dihubungkan dengan konsep-konsep gender. Hasil dari kedua film dibandingkan dan ditarik kesimpulan.

\section{Hasil dan Pembahasan}

Film yang disutradarai laki-laki cenderung lebih laris ketimbang film yang disutradarai perempuan. Seperti yang ditunjukkan di tabel 1, film-film besutan lelaki mampu masuk ke jajaran 10 film terlaris Indonesia. "Warkop DKI Reborn: Jangkrik Boss! Part 1" sebagai film garapan sutradara laki-laki menduduki peringkat pertama film terlaris di Indonesia.
Film ini memiliki penonton sekitar 6,8 juta orang dan meraup keuntungan 240 miliar rupiah. Di posisi ke-2 yaitu film "Dilan 1990" dengan total penjualan tiket 6.315 .664 buah, meraup keuntungan 233 miliar rupiah, serta film "Pengabdi Setan" di posisi ke-6 dengan jumlah penonton 4.206.103 orang serta keuntungan mencapai 155 miliar rupiah. Di sisi lain, film "My Stupid Boss" sebagai film besutan sutradara perempuan terlaris di Indonesia, hanya menduduki peringkat ke-12 di jajaran film terlaris Indonesia dengan tiga juta lebih penonton dan pendapatan sekitar 142 miliar. Tidak hanya menjadi film bersutradara perempuan dengan penjualan tertinggi, film "My Stupid Boss" juga menjadi satu-satunya film Indonesia dari sutradara perempuan yang memperoleh keuntungan di atas 100 miliar rupiah diikuti dengan film "Dua Garis Biru” yang menempati peringkat ke-22 dengan total penjualan tiket 3.052.657 buah dan keuntungan kotor 80 miliar rupiah, serta "Aku Tahu Kapan Kamu Mati" dengan jumlah penonton 567.701 orang dan keuntungan sekitar 20 miliar rupiah.

\begin{tabular}{cllcccc}
\hline $\begin{array}{c}\text { Jenis Ke- } \\
\text { lamin }\end{array}$ & Sutradara & \multicolumn{1}{c}{ Judul } & Tahun & $\begin{array}{c}\text { Peringkat } \\
\text { Terlaris }\end{array}$ & $\begin{array}{c}\text { Jumlah } \\
\text { Penonton }\end{array}$ & $\begin{array}{c}\text { Jumlah Pendapa- } \\
\text { tan }\end{array}$ \\
\hline & $\begin{array}{l}\text { Anggy Um- } \\
\text { bara }\end{array}$ & $\begin{array}{l}\text { Warkop DKI } \\
\text { Reborn: } \\
\text { Jangkrik Boss! } \\
\text { Part 1 }\end{array}$ & 2016 & 1 & 6.858 .616 & Rp240.000.000.000 \\
Laki-laki & & & & & & \\
\cline { 2 - 7 } & $\begin{array}{llllll}\text { Fajar Bus- } \\
\text { tomi, Pidi } \\
\text { Baiq }\end{array}$ & Dilan 1990 & 2018 & 2 & 6.315 .664 & Rp233.000.000.000 \\
\cline { 2 - 7 } & Joko Anwar & Pengabdi Setan & 2017 & 6 & 4.206 .103 & Rp155.000.000.000 \\
\hline \multirow{3}{*}{ Perempuan } & Upi Avianto & My Stupid Boss & 2016 & 12 & 3.052 .657 & Rp142.800.000.000 \\
\cline { 2 - 7 } & Gina S. Noer & Dua Garis Biru & 2019 & 22 & 2.538 .473 & Rp80.000.000.000 \\
\cline { 2 - 7 } & Hadrah & Aku Tahu & 2020 & - & 567.701 & (Sekitar) \\
& Daeng Ratu & $\begin{array}{l}\text { Kapan Kamu } \\
\text { Mati }\end{array}$ & & & & Rp20.000.000.000 \\
\hline
\end{tabular}

Tabel 1. Urutan penjualan tiket dan pendapatan kotor film. Sumber: filmindonesia.orid (2021). 
Posisi peran perempuan dan laki-laki di layar juga bergantung pada penggarap di balik layar film tersebut. Seperti yang ditampilkan di tabel 2 , hanya dua film garapan sutradara laki-laki yang mempunyai protagonis laki-laki; sedangkan dari ketiga film yang disutradarai perempuan semuanya memiliki protagonis perempuan. Ada pula istilah di perfilman bernama top-billing, yaitu nama aktor yang ditampilkan paling awal sebelum penyebutan judul, atau aktor-aktor dengan bayaran tertinggi.
Aktor-aktor tersebut merupakan peran kunci di filmnya. Top-billing biasanya mencakup tiga atau dua peran paling utama pada suatu film. Di antara tiga film besutan sutradara laki-laki, hanya dua film yang mengikutsertakan perempuan di dalam top-billingnya, dengan total top-billing ketiga film adalah enam laki-laki dan dua perempuan. Sementara ketiga film karya sutradara perempuan memiliki perempuan di dalam daftar top-billingnya, dengan total top-billing empat perempuan dan empat laki-laki.

\begin{tabular}{|c|c|c|c|c|c|c|}
\hline Jenis & Sutradara & Judul & Protagonis & Top-billing & \multicolumn{2}{|l|}{ Tes Bechdel } \\
\hline \multirow{12}{*}{ Laki-laki } & \multirow{4}{*}{$\begin{array}{l}\text { Anggy Um- } \\
\text { bara }\end{array}$} & \multirow{4}{*}{$\begin{array}{l}\text { Warkop } \\
\text { DKI Re- } \\
\text { born: } \\
\text { Jangkrik } \\
\text { Boss! Part } 1\end{array}$} & \multirow[t]{4}{*}{ Laki-laki } & \multirow{4}{*}{$\begin{array}{l}\text { 1. Laki-laki } \\
\text { 2. Laki-laki } \\
\text { 3. Laki-laki }\end{array}$} & Dua perempuan & Ya \\
\hline & & & & & Saling berbicara & Tidak \\
\hline & & & & & Hal-hal selain ten- & Tidak \\
\hline & & & & & \multicolumn{2}{|l|}{ Tidak Lolos } \\
\hline & Fajar Bus- & Dilan 1990 & Laki-laki dan & 1. Laki-laki & Dua perempuan & Ya \\
\hline & $\begin{array}{l}\text { tomi, Pidi } \\
\text { Baiq }\end{array}$ & & perempuan & 2. Perempuan & Saling berbicara & Ya \\
\hline & & & & & $\begin{array}{l}\text { Hal-hal selain ten- } \\
\text { tang laki-laki }\end{array}$ & Tidak \\
\hline & & & & & \multicolumn{2}{|l|}{ Tidak Lolos } \\
\hline & Joko Anwar & Pengabdi & Perempuan & 1. Perempuan & Dua perempuan & $\mathrm{Ya}$ \\
\hline & & Setan & & 2. Laki-laki & Saling berbicara & Ya \\
\hline & & & & 3. Laki-laki & $\begin{array}{l}\text { Hal-hal selain ten- } \\
\text { tang laki-laki }\end{array}$ & Ya \\
\hline & & & & & \multicolumn{2}{|l|}{ Lolos } \\
\hline \multirow{12}{*}{$\begin{array}{l}\text { Perem- } \\
\text { puan }\end{array}$} & Upi Avianto & My Stupid & Perempuan & 1. Perempuan & Dua perempuan & Ya \\
\hline & & Boss & & 2. Laki-laki & Saling berbicara & Ya \\
\hline & & & & 3. Lak1-lak1 & $\begin{array}{l}\text { Hal-hal selain ten- } \\
\text { tang laki-laki }\end{array}$ & Ya \\
\hline & & & & & \multicolumn{2}{|l|}{ Lolos } \\
\hline & Gina $S$. & Dua Garis & Laki-laki dan & 1. Laki-laki & Dua perempuan & Ya \\
\hline & Noer & Biru & Perempuan & 2. Perempuan & Saling berbicara & Ya \\
\hline & & & & & $\begin{array}{l}\text { Hal-hal selain ten- } \\
\text { tang laki-laki }\end{array}$ & Ya \\
\hline & & & & & \multicolumn{2}{|l|}{ Lolos } \\
\hline & \multirow{4}{*}{$\begin{array}{l}\text { Hadrah } \\
\text { Daeng Ratu }\end{array}$} & Aku Tahu & \multirow[t]{4}{*}{ Perempuan } & \multirow{4}{*}{$\begin{array}{l}\text { 1. Perempuan } \\
\text { 2. Perempuan } \\
\text { 3. Laki-laki }\end{array}$} & Dua perempuan & Ya \\
\hline & & Kapan & & & Saling berbicara & Ya \\
\hline & & & & & $\begin{array}{l}\text { Hal-hal selain ten- } \\
\text { tang laki-laki }\end{array}$ & Ya \\
\hline & & & & & Lolos & \\
\hline
\end{tabular}

Tabel 2.Top-billing dan seleksi tes Bechdel pada film. 
Semua film yang digarap perempuan juga lolos tes Bechdel, dengan kriteria adanya dua perempuan (bernama) yang saling berinteraksi dan membicarakan hal selain laki-laki; sementara dua dari tiga film yang disutradarai laki-laki tidak lolos kriteria ini. Film "Dilan 1990" tidak lolos karena tiadanya dua perempuan yang saling berbicara mengenai hal selain laki-laki; kalaupun ada, dialog itu dirasa hanya berguna menjadi penambal adegan kosong untuk menyiapkan ke adegan selanjutnya. Sementara film "Warkop DKI Reborn: Jangkrik Boss! Part 1" sendiri sudah tidak lolos bahkan di tahap kedua, yakni dua peran perempuan tidak didapatkan saling berbicara.

\section{Cerita Tentang Perempuan dan Laki-laki di Layar Perak}

Cerita-cerita perempuan seringkali berbeda dengan cerita yang disampaikan laki-laki. Film-film feminin secara eksplisit atau implisit menantang, dan bukannya memuja, representasi dominan dari identitas perempuan (Hankin dikutip Kunsey, 2019). Hal itulah yang membedakannya dari film maskulin. Namun, karakter wanita yang tampak kuat pun dapat dirusak secara naratif dalam narasi film melalui sejumlah kiasan representasional. Berikut hasil analisis penulis akan perbandingan sederet film terlaris besutan sutradara laki-laki dan sutradara perempuan, menurut genre filmnya.

Genre komedi: Warkop DKI: Jangkrik Boss! Part 1 (Anggy Umbara) dan My Stupid Boss (Upi Avianto)

Film pertama (Warkop DKI: Jangkrik Boss! Part 1) berkisah tentang keseharian trio Dono, Kasino, Indro yang berprofesi sebagai polisi, yang harus menjalankan tugasnya menjaga ketertiban ibu kota. Namun, mereka tidak menangani kasus-kasus kriminal dengan baik, sehingga malah membawa mereka ke masalah yang lebih runyam. Film kedua (My Stupid Boss) bercerita tentang perempuan dari Indonesia bernama Diana yang pindah ke Malaysia bersama suaminya, dan memutuskan untuk bekerja di kantor yang dipimpin oleh teman suaminya yang juga berasal dari Indonesia. Diana kemudian terjebak di perusahaan itu dengan empat pekerja lain, menghadapi bosnya yang mengesalkan, pelit, dan eksentrik. Seiring waktu berjalan, mereka bersekongkol untuk membalas perbuatan-perbuatan menyebalkan Bossman dengan cara yang lebih kreatif.

Hal yang penulis temukan dari perbandingan kedua film ini adalah perbedaan penggambaran sikap dan karakter perempuan serta cara peran-peran lain, terutama laki-laki menyikapinya. Melalui analisis, penulis menemukan bahwa peran perempuan di film yang disutradarai laki-laki mayoritas hadir untuk menjadi objek seksual. Empat dari tujuh perempuan yang ditampilkan di film "Warkop DKI Reborn: Jangkrik Boss Part 1" ditampilkan dengan pakaian yang terbuka ataupun ketat. Pengambilan gambar pun difokuskan pada tubuh perempuan, seperti bokong dan dada, atau tubuh perempuan keseluruhan. Mayoritas perempuan juga ditampilkan sebagai pemanis adegan saja, tanpa banyak berkontribusi ke dalam jalan cerita film.

Begitu halnya dengan cara peran-peran di sekitarnya-laki-laki-menyikapi mereka, yakni dengan cara yang mengarah ke arah seksual mulai dari perilaku non-verbal (gestur, pandangan, perilaku) hingga perilaku verbal seperti candaan-candaan yang dilontarkan (tidak hanya sekali) dan ungkapan-ungkapan untuk merespon kehadiran perempuan-perempuan tersebut. Hal itu seringkali dilakukan sehingga penulis melihat bahwa mayoritas perempuan di sana dihadirkan hanya untuk menjadi objek seksual atau untuk menjadi bahan godaan semata. Sebab, kehadiran dari mayoritas peran perempuan di film "Warkop DKI Reborn: Jangkrik Boss! Part 1" tidak banyak memengaruhi alur utama cerita.

Sebaliknya, di fim "My Stupid Boss", sepuluh perempuan yang hadir tidak ditampakkan dengan cara yang mengarah ke hal-hal seksual. Mereka semua tidak memakai baju yang mengekspos banyak bagian tubuh (apalagi yang berbau seksual), dan pengambilan gambar tidak terfokus kepada anggota tubuh yang terbuka itu. Perempuan-perempuan ditem- 
patkan pada peran kunci di film, yang berarti mereka amat krusial bagi jalan cerita.

Cara peran-peran lain, terkhususnya laki-laki, dalam merespon kehadiran perempuan di sana tidak ada yang menuju ke arah seksual. Jalan cerita berfokus kepada lima pekerja dalam menghadapi bosnya yang eksentrik, pelit, dan menyebalkan: hanya lika-liku konflik di antara protagonis, antagonis, dan tirtagonisnya saja. Penulis pun melihat bahwa peran-peran laki-laki di sana menyikapi perempuan dengan perilaku yang lebih positif, yakni dengan sikap yang lebih menghargai dan tidak mengobjektifikasi perempuan melalui perilaku verbal maupun non-verbal.

Mayoritas peran perempuan di film yang dibesut laki-laki ditempatkan di posisi sebagai pendamping dari peran laki-laki belaka. Hal ini terlihat dengan peran pacar gelap seorang direktur perusahaan yang senang bertingkah manja dan bergantung secara finansial kepada pasangannya, dan Sophie sebagai pasangan protagonis dalam cerita yang tidak diberi porsi yang banyak untuk mengambil tindakan. Sophie diperlihatkan sebagai perempuan yang sangat polos, sehingga dalam beberapa adegan ia tidak sadar atau menerima saja godaan-godaan dari protagonis di film. Beberapa peran laki-laki pun memanfaatkan kepolosannya dengan secara terus-menerus melayangkan candaan yang berbau seksual. Hal ini menunjukkan bahwa laki-laki memiliki perlakuan seksis benevolent kepada peran-peran perempuan.

Di sisi lain, di film yang disutradarai perempuan, beberapa peran perempuan di sana justru diperlihatkan lebih mandiri dan tidak bergantung pada laki-laki. Bahkan, sifat mereka juga ditampakkan lebih kuat dan tegas ketimbang pasangannya. Hal ini terlihat dari Diana sang karyawan yang tegas menentang dan mengomeli Bossman jika ia lagi-lagi berulah atau bertingkah tidak masuk akal, Sikin yang selalu menepis godaangodaan dari partner kerjanya, Adrian, dan Bossman yang amat menyebalkan namun patuh dan takut kepada istrinya. Bahkan, istrinya lah yang sering mencari dana investasi untuk perusahaan Bossman, saat melihat pasangannya yang tidak benar dalam bekerja dan terlilit banyak hutang. Ketika Diana mengalami 'musibah-musibah' yang diakibatkan oleh bosnya, ia tidak diperlihatkan dependen pada perlindungan sosok laki-laki lain (suaminya). Ia justru mengerahkan semua kekuatannya untuk bertahan dan melawan ketidakadilan yang ia alami sebagai pekerja.

Diana sebagai protagonis di film ini memiliki karakter yang tidak betah diam di rumah, ingin memiliki hal-hal untuk dikerjakan, tegas, cerdik, dan keras kepala. Sifat-sifat yang tidak ada pada karakter perempuan di film lawannya. Sifat ini juga terbalik dari peran suaminya yang lebih lembut, mengayomi, dan eksentrik, sehingga Diana tampak lebih dominan dibandingkan suaminya. Hal menarik lainnya ialah suaminya diperlihatkan bekerja dari rumah, sementara istrinya bekerja di luar rumah. Hal ini tentu berbeda dari peran gender konvensional yang biasa menempatkan lelaki pada posisi yang lebih dominan, kuat, asertif, bekerja di ranah publik, dan perempuan yang lebih inferior, pasif, lembut, dan bekerja di ranah domestik.

\section{Genre drama remaja: Dilan 1990 (Fajar Bustomi, Pidi Baiq) dan Dua Garis Biru (Gina S. Noer)}

Meski kedua film ini memiliki genre yang serupa (drama remaja), tetapi keduanya membawa genre ini ke arah yang sama sekali berbeda. "Dilan 1990" bercerita tentang remaja SMA, Dilan, yang mendekati anak perempuan baru di sekolahnya, Milea, dengan cara-cara yang unik dan kreatif. Dilan yang merupakan anggota geng motor yang kerap tawuran dengan sekolah lain memicu konflik di antara hubungan percintaannya ketika Milea tidak menyetujui segala aksi perkelahian yang pacarnya gemari. Di sisi lain, "Dua Garis Biru" juga sama-sama bercerita tentang dua remaja SMA yang berpacaran, Dara dan Bima. Namun, cerita tidak berhenti di sana; kedua remaja itu melakukan hubungan seksual yang tidak direncanakan, yang kemudian berujung pada kehamilan. Kehamilan itu datang dengan segala konsekuensi: nama baik keluarga yang 
tercemar, dikeluarkan dari sekolah, masa depan yang menjadi tampak abu-abu, dan segala ketidaksiapan dua remaja SMA dalam menghadapi proses kedewasaan yang dipercepat tanpa mereka mampu lawan.

Di film pertama, penulis melihat bahwa peran utama perempuan digambarkan sebagai sosok yang lembut dan cukup pasif; sedangkan peran utama laki-laki ditampilkan sebagai sosok yang agresif dan percaya diri. Mereka diperlihatkan memiliki dikotomi karakter dan sikap; lelaki-perempuan, mengejar-dikejar, menggoda-menerima, amarah-tangis, melindungi-dilindungi, keras-lembut, pemberontak-patuh, berantakan-rapi, berandal-rajin, agresif-pasif, dan lainnya. Bahkan di sepanjang film, hal utama yang dilakukan peran utama laki-laki terhadap peran utama perempuan adalah melindunginya dari marabahaya, dan menghajar siapapun yang menyakitinya (beberapa peran lelaki diberi kecenderungan melakukan kekerasan fisik ketika emosinya tersulut). Peran utama perempuan digambarkan sebagai sosok yang lebih lemah dan tidak punya daya sekuat peran-peran lawan jenisnya, meneruskan stereotip tradisional gender yang telah ada. Hal ini seperti yang telah dijelaskan oleh Macionis (2000) bahwa laki-laki cenderung digambarkan memiliki karakter maskulin yang secara umum digambarkan mandiri, rasional, kuat, aktif, dan berani; sementara perempuan memiliki karakter feminin yang secara umum digambarkan bergantung pada orang lain, emosional, lemah, dan pasif. Penggambaran laki-laki dan perempuan dalam film pertama juga memperlihatkan adanya seksisme hostile sekaligus seksisme benevolent yang dialami peran utama perempuan.

Di sisi lain, film kedua yang disutradarai perempuan tidak menunjukkan dikotomi perilaku berbasis gender yang kontras di antara kedua jenis kelamin. Tidak ada perilaku khusus dari perlakuan laki-laki ke perempuan di sana, pun sebaliknya. Bahkan, ketika di film pertama tangisan dari peran utama perempuan berbuah pada perkelahian peran utama laki-laki dan orang yang membuatnya menangis, di film kedua tangisan dari peran utama perempuan dibalas dengan perkataan "Enak banget, nangis jadi senjata," dari peran utama laki-laki. Hal ini bagi penulis menampilkan bahwa pasangan di film kedua cenderung setara, tidak memainkan peran pelindung dan yang dilindungi, atau peran satu pasangan pemberi aturan dan pasangan lain yang penurut. Namun, cenderung merepresentasikan pasangan yang sama-sama mempunyai opini masing-masing, tetapi tetap bahu-membahu berusaha menghadapi masalah besar di depan mereka. Di film kedua, memang terdapat adegan-adegan peran laki-laki yang berusaha melindungi peran perempuan, tetapi peran perempuan tidak diperlihatkan dependen pada keberadaan dan bantuan peran laki-laki. Peran perempuan di film kedua pun digambarkan sebagai seseorang yang cerdas, pintar secara akademik, dan memiliki impian yang besar untuk masa depannya sendiri.

Kedua film menampilkan relasi ibu-anak, tetapi perbincangan mereka di antara dua film itu berbeda; yang dibesut laki-laki hanya membicarakan peran utama laki-laki, sementara di film yang digarap perempuan membicarakan masa depan peran utama perempuan, tubuhnya yang berangsur berubah karena kehamilan, dan masa depan bayi yang akan dilahirkan. Penulis melihat bahwa hubungan ibu-anak pada film "Dua Garis Biru" lebih personal dan intim, yang kemudian cenderung memicu pada topik obrolan yang lebih luas.

Penulis belum bisa menemukan pesan moral di film pertama. Hal ini karena konfliknya yang hanya berputar di percintaan remaja dan perkelahian. Selain itu, karena film ini juga masih memiliki sekuel lanjutan yakni "Dilan 1991" yang masih dibesut oleh Fajar Bustomi dan Pidi Baiq. Di film kedua, penulis mendapatkan pesan yang tegas. Film besutan Upi Avianto ini berani membuka topik yang tabu di masyarakat Indonesia, yakni married by accident, ditambah pelakunya yang masih anak remaja SMA yang belum cukup umur.

Film ini berhasil menampilkan fenomena horor yang memang sudah marak terjadi di 
Indonesia, yakni pernikahan di bawah umur. Film ini menampilkan jelas rentetan konsekuensi yang mesti dihadapi kedua pasangan dan kedua pihak keluarganya akan kehamilan yang tidak direncanakan dari remaja yang masih bersekolah di bangku SMA. Proses pendewasaan diri kedua remaja tersebut yang terpaksa dipercepat serta konflik-konflik di antara mereka dan keluarga akan ketidaksiapan-ketidaksiapannya. Film ini menyampaikan secara implisit pentingnya edukasi seks sejak dini, dan membuat topik seks menjadi tabu tidak akan mencegah terjadinya aktivitas seksual. Kemungkinan yang terjadi malah lebih buruk, yakni kehamilan dini yang tidak direncanakan, yang kemudian dapat berimbas buruk tak hanya bagi masa depan pendidikan dan mimpi kedua anak tersebut, tetapi juga risiko kehamilan dini pada tubuh anak perempuan yang belum semestinya mengandung.

Di dalam urusan porsi bicara, di film kedua penulis menemukan bahwa peran ibu dari kedua remaja tersebut cenderung lebih vokal ketimbang suami-suaminya dalam menyampaikan pikiran dan isi hatinya terkait masalah yang kedua keluarga tersebut tengah hadapi. Peran-peran perempuan pun mendapatkan banyak porsi bicara, bahkan cenderung lebih banyak ketimbang laki-laki. Sementara di film pertama, peran perempuan dengan kalimat terbanyak hanyalah peran utama saja, dan porsi bicara peran-peran laki-laki cenderung sama banyaknya ketimbang perempuan. Dialog yang dimiliki peran perempuan pun sebagian besar hanya mengenai laki-laki, tanpa mengeksplorasi topik yang lebih luas untuk mereka. Bahkan, meski porsi bicara peran laki-laki dan peran perempuan cenderung setara, penulis menemukan bahwa peran-peran tirtagonis perempuan di film "Dilan 1990" kebanyakan mendapatkan kalimat yang menjadi jembatan ke adegan lain atau menjadi pendukung saja, tanpa banyak berpengaruh pada jalan cerita. Di sisi lain, karakter-karakter laki-laki tirtagonis di film pertama mendapatkan porsi bicara dan adegan yang berpengaruh besar terhadap jalannya cerita. Hal ini berbeda dengan film "Dua Garis Biru" yang menempatkan peran-peran perempuan untuk memiliki andil besar terhadap jalan cerita. Oleh karena itu, berbeda dengan peran perempuan pertama yang hampir keseluruhan keberadaannya didefinisikan akan hubungannya dengan peran lelaki, penulis menilai peran-peran perempuan di film kedua lebih digambarkan sebagai makhluk tiga dimensi, yang memiliki kedalaman dan digambarkan dengan karakter yang lebih 'utuh'.

\section{Genre horor: Pengabdi Setan (Joko Anwar) dan Aku Tahu Kapan Kamu Mati (Hadrah Daeng Ratu)}

Kedua film horor ini memiliki pengambilan cerita dan tema yang amat berbeda. Film pertama "Pengabdi Setan" dari Joko Anwar mengisahkan tentang Rini dan keluarganya yang harus mengurus ibunya yang sedang sakit. Ketika ibunya wafat, banyak kejadian aneh dan mengerikan yang terjadi di rumahnya. Cerita berlanjut pada penemuan bahwa ibunya yang semasa dulu mandul, mengikuti sekte pemuja setan untuk mendapatkan anak dan ketika anak terakhir yang dilahirkan anggota sekte itu berusia tujuh tahun, ia mesti diserahkan kepada iblis. Film kedua, "Aku Tahu Kapan Kamu Mati " mengisahkan tentang Siena, seorang perempuan yang duduk di bangku SMA, yang dapat melihat hantu selepas mengalami mati suri. Ia menemukan bahwa jika ia melihat hantu bersama dengan seorang manusia, maka tak lama lagi orang itu akan meregang nyawa. Ketika ia melihat arwah mengikuti orang-orang yang ia sayang, ia pun berjuang untuk mencegah mereka menemui ajal.

Jika film pertama menyorot kekeluargaan, film kedua berfokus pada pertemanan dengan tambahan bumbu-bumbu percintaan. Bahkan meski film kedua mempublikasikan dirinya sebagai film horor, aspek komedi dan pertemanan justru lebih kental di film ini, sehingga lebih seperti film komedi dengan bumbu horor.

Penulis melihat bahwa peran-peran perempuan di film pertama tidak mengikuti sifat-sifat tradisional gender yang ada, penulis pun tidak menemukan adanya dikotomi gender yang ekstrem pada peran perempuan dan pe- 
ran laki-laki. Banyak film yang melanggengkan stereotip peran perempuan dan peran laki-laki. Namun, hal tersebut tidak terjadi pada karakter-karakter di film ini. Bahkan protagonis perempuan yang merupakan kakak sulung berperan sebagai kepala keluarga di rumahnya ketika ayahnya harus pergi beberapa hari ke luar kota. Sepanjang cerita, film hanya berfokus pada alur adegan yang semakin lama semakin menakutkan, bukan pada pembagian perilaku, adegan, dan dialog yang memuat peran gender tradisional maupun stereotip gender. Di film kedua, meski obrolan mengenai laki-laki bernama Brama kerap terjadi di antara keempat perempuan itu, banyak hal-hal lain yang mereka juga perbincangkan, seperti kehidupan sehari-hari, pertemanan mereka, kalimat-kalimat yang menggelak tawa, dan tentu saja seperti tema filmnya sendiri, pembicaraan mengenai hantu.

Terdapat peran pemuda yang menemani peran utama perempuan di kedua film. Namun, penulis melihat ada penyikapan yang cenderung berbeda dari mereka dalam menghadapi lawan jenisnya. Meski peran lelaki di film pertama, Hendra, memiliki kecenderungan romantik pada peran utama perempuan, ia lebih menunjukkan sikap ingin membantu dalam masalah-masalah yang sedang dihadapi Rini. Rini sendiri pun menunjukkan sikap yang mandiri dan tidak bergantung pada bantuan yang Hendra tawarkan. Ketika Hendra akhirnya wafat di tengah cerita, hubungan mereka tetap berjalan secara platonis. Tampak jelas bahwa Rini sebagai peran utama perempuan tidak didefinisikan melalui hubungannya dengan lelaki.

Hal ini berbeda dengan peran lelaki di film "Aku Tahu Kapan Kamu Mati”, Brama, yang bertindak dengan cara yang cenderung romantis kepada Siena. Siena pun menyikapi hal itu dengan positif meski ia sama-sama tidak bergantung pada kehadiran Brama. Peran utama perempuan bahkan diperlihatkan beberapa kali menolak bantuan peran laki-laki karena ia merasa dapat melakukannya sendiri. Bahkan ketika ia melihat ada arwah yang mengikuti Brama, pertanda bahwa ia akan wafat tak lama lagi, Siena berusaha untuk melindungi- nya dan mencegah kematiannya.

Kedua film di atas juga memiliki kesamaan dalam porsi adegan dan dialog yang tinggi bagi peran-peran perempuan. Mereka sama-sama menduduki posisi kunci di jalannya cerita, dan bukan hanya sebagai pelengkap ataupun pemanis adegan semata. Bahkan meski peran utama di film Pengabdi Setan tidak banyak berbincang dengan peran perempuan lain, mereka tidak pernah membicarakan hal-hal seputar laki-laki.

\section{Simpulan}

Penggambaran gender dalam film dipengaruhi oleh pelaku di balik layarnya. Berdasarkan upaya membandingkan representasi perempuan pada film yang disutradarai oleh laki-laki seperti "Warkop DKI Reborn: Jangkrik Boss! Part 1", "Dilan 1990", dan "Pengabdi Setan", dengan film besutan perempuan yakni "My Stupid Boss", "Dua Garis Biru", dan "Aku Tahu Kapan Kamu Mati", ditemukan beberapa ketimpangan dalam penggambaran perempuan di layar.

Sutradara perempuan di film-film yang diteliti cenderung menempatkan perempuan di peran-peran kunci dan merepresentasikannya dengan lebih positif. Hal ini tidak seperti di film yang disutradarai oleh laki-laki yang cenderung menempatkan perempuan sebagai pemanis atau pelengkap adegan saja. Semua film yang dibesut oleh perempuan memiliki protagonis perempuan dan lolos tes Bechdel. Sementara dari tiga film besutan lelaki yang diteliti, dua film tidak memenuhi kriteria yang diperlukan untuk lolos tes tersebut. Perempuan di salah satu film buatan lelaki tersebut masih diobjektifikasi secara seksual, dan di film lainnya perempuan tidak ditampilkan seberdaya lawan jenisnya. Beberapa perempuan juga diperlihatkan mendapatkan perlakuan seksisme.

Berdasarkan beberapa film di atas, dapat disimpulkan bahwa dalam film yang disutradarai oleh laki-laki, stereotip gender masih digunakan secara kuat untuk memberikan batasan yang jelas terhadap karakter lelaki dan perempuan, yang tercermin pada perilaku dan isi dialognya. 
Porsi bicara pemeran laki-laki dan perempuan pun sudah mengalami ketimpangan. Padahal, penulis menilai cerita dan adegan yang tidak didasarkan pada nilai-nilai stereotipikal gender cenderung lebih mampu mengeksplorasi topiktopik yang lebih luas dan baru ketimbang filmfilm yang melakukannya.

Perlu untuk memberi kesempatan yang lebih banyak bagi perempuan dalam berkarya melalui media massa, bersamaan dengan dorongan kepada para sutradara, baik laki-laki maupun perempuan, untuk lebih kritis dan melek gender dalam membesut karya-karyanya. Bukan tanpa sebab, dampak dari film-film tersebut bisa lebih besar dan melampaui ranah hiburan semata, yakni terpatrinya nilai-nilai stereotipikal pada masyarakat akan apa yang semestinya terjadi di dunia nyata.

Para sineas tentunya mampu dan boleh mengekspresikan diri melalui karyanya di luar dari pakem-pakem tradisional gender yang selama ini dilestarikan di media massa. Peran-peran di film tidak melulu mesti mengikuti stereotip gender agar cerita dapat berjalan. Menanggalkan pakem-pakem tradisional gender bukan hanya berarti melawan dengan melakukan hal yang sebaliknya. Namun lebih dari itu, melepaskan diri dari pandangan bahwa manusia-manusia di dalam cerita fiksi mesti dibentuk dari lensa gender semata. Ketika embel-embel stereotip gender dilepaskan, dapat terlihat bahwa peran-peran tersebut juga merupakan manusia, yang bertindak selayaknya manusia lain.

\section{Daftar Pustaka}

Alzahrani, F. (2016). The Portrayal of Women and Gender Roles in Films. International Journal of Scientific \& Engineering Research, 7(4), 533-534.

Amelia, R. (2013). Konten Male Gender Role dalam Film. Jurnal E-Komunikasi, 1(2), 221232.

Astuti, Y. D. (2016). Media dan Gender (Studi Deskriptif Representasi Stereotipe Perempuan dalam Iklan di Televisi Swasta). Profetik Jurnal Komunikasi, 9(3), 25-32. https:// doi.org/10.14421/pjk.v9i2.1205

Ayun, P. Q. (2015). Sensualitas dan Tubuh Perempuan dalam Film-Film Horor di Indonesia. Jurnal Simbolika: Research and Learning in
Communication Study, 1(1), 16-23. https:// doi.org/10.31289/simbollika.v1i1.46

Bouchat, K. G. (2019). Testing the Bechdel Test. Portland State University.

Brannon, L. (2017). Gender: Psychological Perspectives (Seventh Edition). New York: Routledge.

Custers, K., dan Bulck, J. V. (2012). The Cultivation of Fear of Sexual Violence in Women. Communication Research, 40(1), 96-124. https://doi.org/10.1177/0093650212440444

England, D. E., Descartes, L., dan Collier-Meek, M. A. (2011). Gender Role Potrayal and the Disney Princesses. Sex Roles, 64, 555-567. https://doi.org/10.1007/s11199-011-9930-7

Fatimah, S., Sili, S., dan Asanti, C. (2019). The Masculinity and Femininity Traits of Female Character in Roth's Insurgent Novel. Jurnal Ilmu Budaya, 3(4), 404-412. http://dx.doi. org/10.30872/jbssb.v3i4.2295

Film Indonesia. (2021). 15 Film Indonesia Peringkat Teratas dalam Perolehan Jumlah Penonton pada Tahun 2007-2021 Berdasarkan Tahun Edar Film. Dikutip 15 Mei 2021, dari http://filmindonesia.or.id/movie/viewer/2007-2021\#.YNClmEwxXIU

Garcia, D., Weber, I., dan Garimella, V. R. K. (2013). Gender Asymmetris in Reality and Fiction: The Bechdel Test of Social Media. The International AAAI Conference on Weblogs and Social Media, 1-23. California: The AAAI Press.

Kunsey, I. (2019). Representations of Women in Popular Film: A Study of Gender Inequality in 2018. Elon Journal of Undergraduate Research in Communications, 10(2), 27-38.

Macionis, J. J. (2000). Sociology: Eight Edition. New Jersey: Prentice Hall.

Montasseri, Z., Khaghaninejad, M. S., dan Moloodi, A. (2020). Gender Representation in American Movies: A Corpus-based Analysis. The International Journal of Humanities, 27(4), 42-53.

Morgan, M., dan Shanahan, J. (2010). The State of Cultivation. Journal of Broadcasting \& Electronic Media, 54(2), 337-355. https:// doi.org/10.1080/08838151003735018

Nurwahyuni, E. E. (2015). Gender Role Construction and Its Impact Portrayed in The Galass Menagerie Play. Journal of Literature, Linguistics and Cultural Studies, 4(1), 20-29. https://doi.org/10.15294/rainbow.v4i1.7369

Onea, A. N. (2015). Culture and Gender Role Differences. Cross-Cultural Management Journal, 17(1), 31-35. 
Suara Pembaruan. (2020). 2019, Angka Penonton Film Indonesia Tumbuh Positif. Dikutip dari https://www.idx.co.id/StaticData/NewsAndAnnouncement/ANNOUNCEMENTSTOCK/From_EREP/202001/33560c7178 cfb30130b7.pdf

Perdana, D. (2014). Stereotip Gender dalam Film Anna Karenina. Jurnal Interaksi, 3(2), 123-130. https://doi.org/10.14710/interaksi.3.2.123-130

Piano, T. D., Gerino, E., Marino, E., Brustica, P., dan Rolle, L. (2014). Gender and Media Representation. Romanian Journal of Experimental Applied Psychology, 5(4).

Umarella, F. (2012). Media dan Budaya Populer. Jurnal Komunika, 15(1), 11-15. 